\title{
Effect of Walking Exercise on Blood Parameters in Patients with Type 2 Diabetes Mellitus
}

\section{Tip 2 Diabetes Mellituslu Hastalarda Yürüme Egzersizinin Kan Parametrelerine Etkisi}

\author{
(1) Raziye Șavkın¹, (1) Nihal Büker¹, (1) Gökhan Bayrak², (D) Gülsüm Oğuz¹, (D) Șenay Topsakal3 \\ 1Pamukkale University, School of Physical Therapy and Rehabilitation, Denizli, Turkey \\ ${ }^{2}$ Muș Alparslan University Faculty of Health Sciences, Department of Physiotherapy and Rehabilitation, Muș, Turkey \\ 3Pamukkale University Faculty of Medicine, Department of Endocrinology and Metabolism, Denizli, Turkey
}

\begin{abstract}
Introduction: Lifestyle modification is the first-line treatment for the management of patients with type 2 diabetes mellitus (T2DM). Patient education and the use of technological tools that will increase compliance with the exercise program may increase physical activity in these patients. In this study, we aimed to examine the effect of pedometer-based walking intervention on clinical, diabetes-related cognitive and social factors, and quality of life outcomes in patients with T2DM.
\end{abstract}

Methods: Forty patients (17 male and 23 female) were randomly divided into the intervention $(n=20 ; 13$ male and 7 female) and control ( $n=20 ; 4$ male and 16 female) groups. Both groups received diabetes education program, and instant messaging and calling application were used to facilitate and increase the communication between patients and researchers. The intervention group underwent the brisk walking program (40 minute/day and 3 times/week) for 12 weeks. The outcomes included the plasma glucose, hemoglobin A1c (HbA1c), blood lipids, body mass index, International Physical Activity Questionnaire-Short Form (IPAQ-SF), Multidimensional Diabetes Questionnaire, SF-36, and daily number of steps.

Results: The HbA1c level decreased significantly in the intervention group $(p=0.020)$. No statistically significant difference was observed within and between groups in terms of the plasma glucose and lipid levels $(p \geq 0.05)$. The IPAQSF walking and total physical activity scores increased in the intervention group $(p<0.001)$ and had better results in diabetes-related cognitive and social factors and the quality of life $(p<0.001)$.

Conclusion: Diabetes education, mobile phone application, and motivational strategies can increase the level of physical activity in patients with T2DM. Increased physical activity may have positive effects on glycemic control, diabetes-related selfefficacy, and the quality of life.

Keywords: Smartphone, pedometer applications, brisk walking, glycemic index, quality of life

\section{öz}

Amaç: Tip 2 diabetes mellituslu (T2DM) hastalarda yașam tarzı değişikliği, ilk basamak tedavi seçeneğidir. Hasta eğitimi ve egzersiz programına uyumu artıracak teknolojik araçların kullanımı bu hastaların fiziksel aktivite düzeyini artırabilir. Bu çalışmada, T2DM'li hastalarda pedometre ile takip edilen yürüme müdahalesinin klinik sonuçlara, diyabetle ilișkili bilişsel ve sosyal faktörlere ve yaşam kalitesine etkisini incelemeyi amaçladık.

Yöntemler: Kırk hasta (17 erkek, 23 kadın) müdahale ( $n=20$, 13 erkek, 7 kadın) ve kontrol ( $n=20,4$ erkek, 16 kadın) olmak üzere rastgele iki gruba ayrıldı. Her iki gruba da başlangıçta diyabet eğitim programı verildi ve iletişimi kolaylaștırmak ve artırmak için anlık mesajlașma ve arama uygulaması kullanıldı. Müdahale grubuna 12 hafta boyunca tempolu yürüyüş programı (40 dakika/gün ve 3 kez/hafta) uygulandı. Sonuç ölçümlerini plazma glukozu, hemoglobin A1c (HbA1c), kan lipidleri, vücut kitle indeksi, Uluslararası Fiziksel Aktivite Anketi-Kısa Form (IPAQ-SF), Çok Boyutlu Diyabet Anketi, SF-36 ve günlük adım sayısı oluşturdu.

Bulgular: Müdahale grubunda HbA1c düzeyi anlamlı olarak azaldı $(p=0,020)$. Plazma glukoz ve lipid düzeylerinde grup içinde ve gruplar arasında istatistiksel olarak anlamlı fark yoktu $(p \geq 0,05)$. Müdahale grubunun IPAQ-SF yürüme ve toplam fiziksel aktivite puanında artış saptandı $(p<0,001)$ ve diyabetle ilişkili bilişsel ve sosyal faktörler ile yaşam kalitesi açısından da müdahale grubunda daha iyi sonuçlar elde edildi $(p<0,001)$.

Sonuç: T2DM'li hastalarda diyabet eğitimi, cep telefonu uygulaması ve motivasyon stratejileri fiziksel aktivite düzeyini artırabilir. Artan fiziksel aktivite, glisemik kontrol, diyabetle ilişkili öz yeterlilik ve yaşam kalitesi üzerinde olumlu etkilere sahip olabilir.

Anahtar Kelimeler: Akıllı telefon, pedometre uygulamaları, tempolu yürüyüş, glisemik indeks, yaşam kalitesi 


\section{Introduction}

Diabetes mellitus (DM) is a chronic, non-communicable, metabolic disorders characterized by high blood glucose levels. International Diabetes Federation reported that 463 million people have diabetes in 2019, and this number is projected to reach 578 million by 2030 and 700 million by 2045. Type 2 diabetes mellitus (T2DM) is the most common type of diabetes (around 90\%) of diabetes worldwide (1). T2DM is the result of a complex combination of genetic, epigenetic, and environmental/lifestyle factors. Environmental/lifestyle risk factors include energy-dense Western-style diets, decreased physical activity, increased sitting and monitor viewing time, exposure to noise or fine dust, short or disturbed sleep, smoking, stress, depression, and low socioeconomic status (2).

Obesity and physical inactivity as a result of global urbanization may be the main reason for the increased burden of diabetes (3). A total of $28.2 \%$ of diabetic patients in the ultrasound reported achieving the recommended level of physical activity (4). However, exercise or physical activity is one of the most important treatment methods used in the clinical management of individuals with T2DM and has been included in numerous guidelines (5). Sedentary lifestyles are greatly influenced by increasing technological (such as elevator use, motor vehicle use, etc.) developments. In addition, the facilitation of communication by mobile phones and the loss of mobility required for face-to-face interviews negatively affects patients with T2DM and everyone else. However, with the well-integrated use of technology, changes in lifestyle can be supported, and adaptation to exercise training can be increased, thus ensuring the effective management of diabetes (6).

The use of smartphones to support physical activity offers unique, feasible, and cost-effective opportunities for clinicians and patients to improve rehabilitation (7). Therefore, using a pedometer increase physical activity and improve several health outcomes, at least in the short term (8). In our study, we downloaded a free pedometer application to the smartphone and aimed to examine the effect of the pedometerbased walking intervention on clinical, diabetes-related cognitive, and social factors and the health-related quality of life outcomes in patients with T2DM.

\section{Methods}

\section{Participants}

Patients diagnosed with T2DM and who applied to the Endocrinology and Metabolic Diseases Department in Pamukkale University were enrolled in the study. The study was approved by the Pamukkale University NonInterventional Clinical Research and Ethics Committee to which the authors are affiliated (approval number: 60116787-020/47020, date: 11/07/2018). Informed consent was obtained from all patients.

The inclusion criteria were as follows: ages between 18-65 years old, a diagnosis of T2DM for at least 6 months in accordance with the American Diabetic Association's Standards of Medical Care in Diabetes, a hemoglobin A1c (HbA1c) level higher than 7\%, capability to use a smartphone and communicate orally and in writing with a phone and message application. The exclusion criteria were as follows: engagement in regular exercise or physical activity program within the last 3 months, and concurrent pathologies that affect the ability to perform physical activity or everyday tasks (e.g., cardiac autonomic neuropathy, severe peripheral neuropathy, decompensated heart failure, myocardial infarction or stroke history, cancer, and extremity amputation).

A total of sixty eight patients were assessed for eligibility. Twenty-eight patients who did not meet the inclusion criteria were excluded from the study due to the lack of a smartphone $(n=4)$, presence of concurrent pathologies $(n=15)$, and engagement in regular exercises $(n=9)$. Finally, forty patients (17 male and 23 female) were randomly divided into the intervention ( $n=20 ; 13$ male and 7 female) and control $(n=20 ; 4$ male and 16 female) groups using computer-generated random numbers.

\section{Interventions}

All patients were given an education program about the definition of DM, symptoms, risk factors, types, treatment and complications, main aspects of self-care of the disease (foot care, eye care, and blood glucose monitoring), main aspects of dietary management, weight reduction, physical activity, blood pressure, smoking cessation, periodic investigations, and home monitoring (9). Booklets concerning all these issues were also handed out to all patients. Patients' pharmacological treatment were unaltered during the study, and no recommendations were given concerning changes in dietary habits.

All the patients were asked to install a free pedometer application (Runtastic Pedometer), which is compatible with all smartphones to record their number of steps. Presset et al. (10) recommended strapping the smartphone on the arm as tightly as possible for an accurate step count. Therefore, the patients were instructed to strap their phones on their arm from the moment they woke up until just before bedtime. The daily step count of both groups for 12 weeks was monitored with this application.

The intervention group walked outdoors (on a promenade) for 40 minute at a self-selected brisk speed three times a week for 12 weeks as a guideline for selecting a "brisk" walking pace (as per the current physical activity recommendations); they were told to imagine that they were walking as if they were in a hurry to catch a bus. This instruction was used successfully in other studies $(11,12)$ to ensure that the participants walk with moderate intensity. The control group was not given a walking intervention and instructed not to change their diet and activity levels during the study.

In the first week, patients were called twice at an interval of 3 days to ensure that they were using the smartphone pedometer application appropriately. In addition, WhatsApp Messenger (WhatsApp Inc.) groups were created for both groups to facilitate and increase the communication between patients and researchers. During the study, reminder text messages were sent to the patients from WhatsApp groups 3 days a week. The intervention group was called, "Take the steps and beat diabetes!" The messages sent to this group were as follows: "Today is Monday! Your exercise day. Do not forget to check your blood sugar and walk for 40 minutes," and "Having a busy day does not prevent you from exercising; let's go for a walk!" The control group was called "We follow your daily steps!" The messages sent to this group were as follows: 
"Today is Monday! Have a good day!"; "Good Morning! Do not forget to check your pedometer application."

\section{Measurements}

The demographic data of the patients [age, gender, body mass index (BMI), occupation, etc] and medical history (years with T2DM, comorbidity, the number of drugs taken per day, medication, etc) were recorded. Evaluations were performed at baseline and after 12 weeks.

Blood samples obtained during fasting and postprandial [fasting plasma glucose, postprandial glucose, HbA1c, and lipid levels (total cholesterol, high-density lipoprotein and low-density lipoprotein cholesterol, and triglycerides] were measured.

Anthropometric data were collected by a blinded trained investigator. The patients dressed lightly and stood barefoot during measurement. The patients' height and weight were assessed using a Charder MS3400 device. BMI was calculated by dividing the weight in kilograms by the height in meters squared.

International Physical Activity Questionnaire-Short Form (IPAQ-SF, self-administered version) was used to assess the types of intensity of physical activity (vigorous- and moderate- intensity activity; walking) and sitting time that patients perform as part of their daily activities for the last 7 days. The combined total physical activity score was calculated and expressed in metabolic equivalent minutes per week (13).

The Multidimensional Diabetes Questionnaire (MDQ) was designed by Talbot to provide a comprehensive assessment of diabetes-related cognitive and social factors (14). The Turkish version of the MDQ is reliable and valid and is divided into three sections and six subdimensions. Section I includes the general perceptions of diabetes and related social support consisting of three dimensions: interference (9 items), severity (3 items), and social support (11 items). A high score indicates a high interference, severity, and social support. Section II comprises the social incentives related to self-care activities and consists of one dimension, that is, misguided support behaviors (4 items). High scores indicate misguided support behaviors. Section III represents the self-efficacy and outcome expectancies consisting of two dimensions: self-efficacy (7 items) and outcome expectancies (6 items). A high score indicates improved self-efficacy and outcome expectations (15).

SF-36 was used to determine the patients' health-related quality of life. The questionnaire consists of 36 items and provides scores on eight subscales: physical functioning, role limitations due to physical problems, bodily pain, general health perceptions, mental health, role limitations due to emotional problems, social functioning, and vitality. The total score of the questionnaire ranges from 0 to 100 , with a high score indicating a good quality of life (16).

\section{Statistical Analysis}

The data were analyzed using SPSS 24.0 (IBM Corp. Released 2016. IBM SPSS Statistics for Windows, Version 24.0. Armonk, NY: IBM Corp.) package program. Continuous variables were given as mean \pm standard deviation and median (minimum and maximum), and categorical variable values are presented as absolute numbers (n) and percentages (\%). The conformity of continuous variables with normal distribution was evaluated using the Kolmogorov-Smirnov test. For comparison of the data between baseline and after 12 weeks measurements, pairedsample t-test for parametric test assumptions and Wilcoxon paired signed test for non-parametric test assumptions were used. The difference in changes between groups during the intervention was calculated based on their baseline levels, and Independent sample t-test for parametric test assumptions and Mann-Whitney $U$ test for non-parametric test assumptions were used for comparison of the groups. The chi-square test was used for categorical variables. Statistical significance was set at $\mathrm{p} \leq 0.05$.

\section{Results}

The patients in the intervention group (mean age: 53.90 years; 7 women and 13 men) have been diagnosed with T2DM for $8.45 \pm 6.57$ years, whereas those in the control group (mean age: 48.85 years; 16 women and 4 men) have been diagnosed for $9.95 \pm 6.42$ years. Table 1 provides the descriptive characteristics of the patients.

The intervention group attained an average of $6251.70 \pm 2722.15$ steps per day, whereas the control group made 661.05 \pm 501.52 steps.

The HbA1c level decreased significantly in the intervention group after 12 weeks $(p=0.02)$. No statistically significant difference was observed within and between groups in terms of their plasma glucose, HbA1c, and lipid levels ( $p \geq 0.05$ ) (Table 2).

IPAQ-SF walking $(p=0.00)$ and total physical activity $(p=0.00)$ scores increased significantly in the intervention group after pedometer-based walking intervention. However, no change was noticed in the IPAQ-SF score of the control group. A significant difference was observed in favor of the intervention group in terms of the difference in between-group changes $(p=0.00)$ (Table 2$)$.

According to MDQ part I scores, no change in the intervention and control groups occurred during the 12-week period. However, a significant difference in favor of the intervention group was observed in terms of the difference in between-group changes regarding Section I-interference score $(p=0.01)$. Section II-misguided support behaviors and Section III-self-efficacy scores of the intervention group improved at the end of 12 weeks ( $p=0.001$ ), but no difference was observed in the control group $(p \geq 0.05)$. However, a significant difference in favor of the intervention group was recorded in terms of the difference in betweengroup changes $(p=0.001, p=0.03)$. For the intervention $(p=0.001)$ and control groups $(p=0.02)$, a significant increase in Section III-outcome expectancies scores was observed after 12 weeks (Table 2).

No statistically significant change was observed in SF-36 physical functioning, social functioning, role physical, role emotional, and pain subscales in within- and between-group comparisons ( $p \geq 0.05)$. General health perceptions $(p=0.001)$, mental health $(p=0.01)$, and energy/ vitality ( $p=0.01$ ) scores increased significantly in the intervention group after 12 weeks. A significant difference in favor of the intervention group was noticed in terms of the between-group differences in these scores (general health perceptions: $p=0.001$, mental health: $p=0.001$, energy/ vitality: $p=0.01$ ) (Table 2 ). 
Table 1. Descriptive characteristics of patients

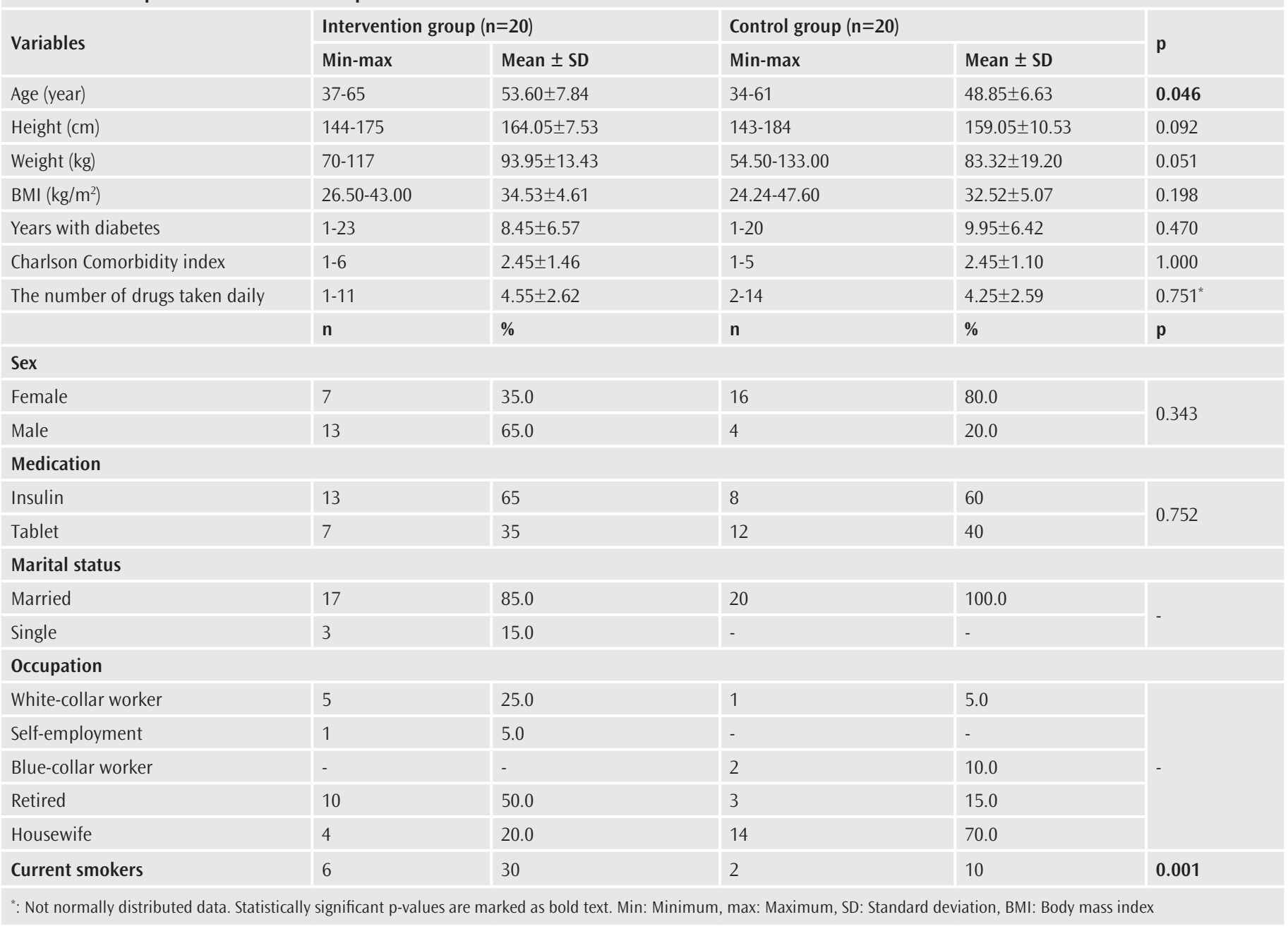

\section{Discussion}

The main goal of this study was to examine the effect of pedometerbased walking intervention on clinical, diabetes-related cognitive, and social factors and the health-related quality of life outcomes in patients with T2DM. Our results indicated that pedometer-based walking intervention has beneficial effects on physical activity, HbA1c level, social incentives related to self-care activities, diabetes-related selfefficacy, outcome expectancies, and general health perceptions, mental health, and vitality.

Counselling and effective and culturally oriented education intervention play an important role in achieving the patients' quality of life, mobility, self-care, and daily living activities (17). Diabetes education also enhances patients' and families' self-care knowledge, health skills, and confidence, allowing them to take increasing control of their lives. In addition, a significant decrease was observed in fasting blood glucose after educational intervention in patients with T2DM (9). Our study aimed to raise awareness about diabetes care, self-care, and daily vital activities by providing versatile diabetes training to type 2 diabetic patients and their relatives, and the results showed that diabetes education had useful effects on patients with T2DM.
Smartphone-based pedometer applications and connected wristbands are becoming widespread, and new technologies must be considered as a complementary tool to help populations reach physical activity recommendations to promote physical health $(10,18)$. New communication and control methods provided by smartphones also have the potential to provide patients with reinforcement, measure intervention impact, and improve patient care on a large scale (18). A cognitive-behavioral approach and smartphone-assisted pedometer application promise to increase physical activity in patients with T2DM and is a good method to provide health counseling (19). For this purpose, a smartphone-based application was installed on each patient's phone, and the patients were instructed to strap their phones on their arm from the moment they got up until just before bedtime. Our results showed that the smartphone-based application has a beneficial effect on increasing physical activity in patients with T2DM.

Lifestyle modifications, such as a caloric restricted diet, reduced sedentary behavior, and increases in exercise, are the first-line treatment for the management of T2DM. Physical inactivity is a strong predictor for all-cause mortality (20), and an increase in physical activity can prevent or delay T2DM. However, different results have been reported regarding the effects of walking training on glycemic control in patients with 
Table 2. Comparison of clinical- and patient-reported outcome scores of the groups

\begin{tabular}{|c|c|c|c|c|c|c|c|}
\hline \multirow[b]{2}{*}{ Variables } & \multicolumn{3}{|c|}{ Intervention group $(n=20)$} & \multicolumn{3}{|c|}{ Control group $(n=20)$} & \multirow[b]{2}{*}{$\Delta p$} \\
\hline & $\begin{array}{l}\text { Baseline } \\
\text { (mean } \pm \text { SD) }\end{array}$ & $\begin{array}{l}\text { 12-weeks } \\
\text { (mean } \pm \text { SD) }\end{array}$ & $\mathbf{p}$ & $\begin{array}{l}\text { Baseline } \\
\text { (mean } \pm \text { SD) }\end{array}$ & $\begin{array}{l}\text { 12-weeks } \\
\text { (mean } \pm \text { SD) }\end{array}$ & $\mathbf{p}$ & \\
\hline BMI $\left(\mathrm{kg} / \mathrm{m}^{2}\right)$ & $34.53 \pm 4.61$ & $34.50 \pm 4.10$ & 0.91 & $32 \pm 52 \pm 5.07$ & $33.06 \pm 5.56$ & 0.21 & 0.46 \\
\hline Weight (kg) & $93.95 \pm 13.43$ & $92.92 \pm 13.48$ & 0.13 & $83.32 \pm 19.20$ & $83.87 \pm 19.31$ & 0.22 & 0.05 \\
\hline \multicolumn{8}{|l|}{ IPAQ-SF } \\
\hline Walking score (MET-min/wk) & $357.22 \pm 404.92$ & $1419 \pm 740.38$ & $0.00^{*}$ & $350.62 \pm 393.71$ & $358.05 \pm 372.28$ & $0.68^{*}$ & $0.00^{*}$ \\
\hline Total activity score (MET-min/wk) & $405.22 \pm 440.40$ & $2025 \pm 1577.12$ & $0.00^{*}$ & $502.02 \pm 588.18$ & $538.05 \pm 598.16$ & $0.47^{*}$ & $0.00^{*}$ \\
\hline \multicolumn{8}{|l|}{ Glycemic control } \\
\hline Fasting plasma glucose & $142.25 \pm 28.70$ & $139.890 \pm 22.49$ & 0.46 & $141.58 \pm 52.99$ & $135.25 \pm 33.67$ & 0.39 & $0.88^{*}$ \\
\hline Postprandial glucose & $195.50 \pm 86.58$ & $203.55 \pm 63.04$ & 0.60 & $193.25 \pm 90.04$ & $201.95 \pm 62.23$ & 0.79 & 0.85 \\
\hline $\mathrm{HbA1c}(\%)$ & $7.76 \pm 0.74$ & $7.32 \pm 1.08$ & $0.02^{*}$ & $7.64 \pm 0.79$ & $7.45 \pm 1.35$ & $0.26^{*}$ & $0.41^{*}$ \\
\hline \multicolumn{8}{|l|}{ Lipids } \\
\hline Total cholesterol (mmol/L) & $173.90 \pm 34.23$ & $173.35 \pm 31.67$ & 0.95 & $171.10 \pm 40.89$ & $167.95 \pm 43.85$ & 0.74 & 0.84 \\
\hline HDL cholesterol (mmol/L) & $43.85 \pm 14.25$ & $46.85 \pm 17.24$ & $0.28^{*}$ & $48.60 \pm 12.36$ & $49.65 \pm 12.53$ & $0.66^{*}$ & $0.64^{*}$ \\
\hline LDL cholesterol (mmol/L) & $96.75 \pm 25.85$ & $90.05 \pm 29.95$ & 0.42 & $99.55 \pm 42.58$ & $93.45 \pm 30.11$ & 0.48 & 0.96 \\
\hline Triglycerides (mmol/L) & $153.12 \pm 54.47$ & $154.47 \pm 56.10$ & 0.65 & $148.70 \pm 65.98$ & $141.90 \pm 54.69$ & 0.59 & $0.50^{*}$ \\
\hline \multicolumn{8}{|l|}{ MDQ } \\
\hline Section I-interference & $1.78 \pm 1.17$ & $1.41 \pm 1.01$ & 0.08 & $2.15 \pm 1.86$ & $2.35 \pm 2.12$ & 0.11 & $0.01^{*}$ \\
\hline Section I-severity & $4.02 \pm 1.87$ & $4.29 \pm 1.82$ & 0.42 & $4.78 \pm 1.64$ & $4.98 \pm 1.71$ & $0.59^{*}$ & $0.56^{*}$ \\
\hline Section I-social support & $3.77 \pm 1.91$ & $3.72 \pm 1.92$ & $0.91^{*}$ & $3.50 \pm 2.20$ & $3.59 \pm 2.16$ & $0.09^{*}$ & $0.51^{*}$ \\
\hline Section II-misguided support behaviors & $0.58 \pm 0.64$ & $0.29 \pm 0.46$ & $0.00^{*}$ & $0.39 \pm 0.89$ & $0.66 \pm 0.98$ & $0.07^{*}$ & $0.00^{*}$ \\
\hline Section III-self-efficacy & $48.88 \pm 19.73$ & $68.89 \pm 20.19$ & $0.00^{*}$ & $54.32 \pm 22.51$ & $61.21 \pm 24.96$ & 0.07 & 0.03 \\
\hline Section III-outcome expectancies & $88.89 \pm 11.04$ & $96.66 \pm 5.19$ & $0.00^{*}$ & $91.74 \pm 11.85$ & $97.00 \pm 9.23$ & $0.02^{*}$ & $0.07^{*}$ \\
\hline \multicolumn{8}{|l|}{ SF-36 } \\
\hline General health perceptions & $53.25 \pm 18.80$ & $67.00 \pm 19.49$ & 0.00 & $59.75 \pm 20.42$ & $58.88 \pm 16.11$ & 0.66 & $0.00^{*}$ \\
\hline Physical functioning & $83.25 \pm 16.96$ & $87.75 \pm 15.52$ & $0.07^{*}$ & $77.75 \pm 26.08$ & $77.75 \pm 24.25$ & $0.93^{*}$ & $0.11^{*}$ \\
\hline Mental health & $58.20 \pm 22.76$ & $65.80 \pm 22.83$ & $0.01^{*}$ & $61.60 \pm 10.65$ & $60.15 \pm 12.43$ & 0.25 & $0.00^{*}$ \\
\hline Social functioning & $76.88 \pm 19.98$ & $83.13 \pm 18.26$ & $0.14^{*}$ & $70.25 \pm 21.85$ & $72.38 \pm 18.04$ & $0.29^{*}$ & $0.25^{*}$ \\
\hline Role physical & $81.25 \pm 30.21$ & $76.25 \pm 32.92$ & $0.51^{*}$ & $72.50 \pm 42.07$ & $75.00 \pm 34.41$ & $0.91^{*}$ & $0.60^{*}$ \\
\hline Role emotional & $56.67 \pm 39.15$ & $65.01 \pm 42.54$ & $0.36^{*}$ & $48.33 \pm 46.49$ & $47.50 \pm 40.93$ & $0.89^{*}$ & $0.32^{*}$ \\
\hline Pain & $77.13 \pm 22.19$ & $84.50 \pm 15.76$ & $0.12^{*}$ & $65.88 \pm 26.05$ & $64.25 \pm 28.51$ & 0.44 & $0.10^{*}$ \\
\hline Energy/vitality & $52.25 \pm 26.03$ & $62.00 \pm 26.33$ & $0.01^{*}$ & $57.25 \pm 20.29$ & $56.09 \pm 21.11$ & 0.56 & $0.01^{k}$ \\
\hline Daily number of steps & - & $6251.70 \pm 2722.15$ & - & - & $661.05 \pm 501.52$ & $0.00^{*}$ & - \\
\hline
\end{tabular}

T2DM $(21,22)$. Studies indicated that walking training can be applied in patients with T2DM but has little or no beneficial effect on glycemic control (HbA1c, fasting glucose, and postprandial glucose) (22); on the contrary, gait training improves glycemic control (21-23). Although not statistically significant, gait training improved glycemic controls in both groups. This finding may be due to the participation of both groups in diabetes education. In addition, a significant decrease in $\mathrm{HbA1c}$ level was observed in those who participated in the12-week pedometerbased walking program. Web and mobile health interventions used for behavioral interventions provide trends for benefits in diabetes selfefficacy, adherence, and glycemic control (6). We think that utilizing technological tools, which will increase compliance with the exercise program in addition to patient education, provides extra benefits for patients with T2DM.

Smartphone applications and computer-led health coaching can increase the physical activity level and exercise adherence in type 2 diabetic patients (18). Pedometer applications are frequently used in health promotion because they are easy to use, low cost, motivational, and self-monitoring (24). Pedometers are also effective tools to increase the level of physical activity among type 2 diabetic patients in the short term $(25,26)$. The increase in physical activity level does not reflect the lipid level in these patients at the same rate. The overwhelming majority of studies have shown the absence of effect of any exercise training on lipids, such as high-density lipoprotein, low-density 
lipoprotein, cholesterol profile and triglycerides, in relation to T2DM (23). In agreement with other studies, although the pedometer-based walking intervention increased physical activity level, it did not cause a statistically significant difference in the lipid profile.

Given the complex nature of T2DM, which is affected by cognitive and social factors, diabetes management includes multi-component selfcare activities and lifestyle changes. In addition to clinical evaluation, psychosocial evaluations should be conducted and considered the following: such as the level of the diabetic's daily activities affected by diabetes (interference), the degree to which diabetics perceive the severity of diabetes (severity), social support provided by important people and healthcare professionals in the life of the diabetic (social support), supportive and misguided support behaviors of diabetic relatives (misguided support behaviors), the diabetic's self-confidence in performing self-care activities (self-efficacy), perceived importance of self-care behaviors, and the effectiveness of treatment in the metabolic control and prevention of complications (outcome expectancies) (15). In our study, outcome expectations increased in both intervention and control groups. With diabetes education and the messages we have sent, the patients' perception levels of the importance of self-care behavior and the treatment effectiveness may have increased. In addition, the intervention group had a decrease in misguided support behavior and an increase in self-efficacy. Regular walking may have increased the encouragement of family members about disease management, and increased physical activity may have led to the development of selfefficacy $(27,28)$. In addition, the intervention group had better results in terms of interference, misguided support behaviors, and self-efficacy. A relationship exists between perceived interference, support, and positive outcome expectations with self-efficacy in patients with T2DM (29). With education, daily reminder messages, and walking intervention, the patients' self-management can be improved.

Quality of life measures is used in healthcare field to evaluate the healthcare outcomes in chronic conditions in which major health problems may persist (23). Understanding the dimensions of quality of life associated with diabetes and its comorbidities is important for the clinical management of the disease (30). Physical activity improves the quality of life of patients with T2DM $(23,31)$ Our study yielded results similar to those of previous research. Encouraging sedentary patients with T2DM to increase their physical activity may improve their quality of life.

\section{Study Limitations}

The current study presented several limitations. When the Runtastic Pedometer was improperly connected, whether the phone can distinguish steps and movements or count steps when the patient was using the phone was unclear. In our study, the status of patients holding the phone to their arms throughout the day could not be controlled. The patients and their families were educated on diabetes and were told to continue their recommended diet. However, dietary compliance could not be tracked. Therefore, the statements of the patients about their dietary compliance were relied on. However, dietary habits could also be followed by smartphone applications.

\section{Conclusion}

In this study, we aimed to examine the effect of the pedometer-based walking intervention, which was performed three times a week for 12 weeks, on the clinical, diabetes-related cognitive, and social factors and the quality of life outcomes in patients with T2DM. We observed that walking had beneficial effects on the patients' physical activity, $\mathrm{HbA1c}$ level, social incentives related to self-care activities, diabetesrelated self-efficacy, outcome expectancies, general health perceptions, mental health, and vitality. The findings of the current study indicated that diabetes education, smartphone-based pedometer application, and motivational strategies can increase the level of physical activity in patients with T2DM. Increased physical activity can have positive effects on glycemic control, diabetes-related self-efficacy, and the quality of life.

Ethics Committee Approval: The study was approved by the Pamukkale University Non-Interventional Clinical Research and Ethics Committee to which the authors are affiliated (approval number: 60116787020/47020, date: 11/07/2018)

Informed Consent: Informed consent was obtained from all patients.

Peer-review: Externally peer-reviewed.

Authorship Contributions: Surgical and Medical Practices - S.T.; Concept - Ş.T., N.B., R.Ş.; Design - N.B., R.Ş., G.B.; Data Collection or Processing - R.S., G.O., G.B.; Analysis or Interpretation - N.B., R.S., S..T.; Literature Search - R.Ş., G.O., G.B.; Writing - N.B., R.Ş., G.O.

Conflict of Interest: No conflict of interest was declared by the authors.

Financial Disclosure: The authors declared that this study received no financial support.

\section{References}

1. IIDF. IDF Diabetes Atlas. 2015. https://idf.org/e-library/epidemiologyresearch/diabetes-atlas/13-diabetes-atlas-seventh-edition.html

2. Kolb H, Martin S. Environmental/lifestyle factors in the pathogenesis and prevention of type 2 diabetes. BMC Med 2017; 15: 131.

3. Asif M. The prevention and control the type-2 diabetes by changing lifestyle and dietary pattern. J Educ Health Promot 2014; 3: 1.

4. Resnick HE, Foster GL, Bardsley J, Ratner RE. Achievement of American Diabetes Association clinical practice recommendations among US adults with diabetes, 1999-2002: the National Health and Nutrition Examination Survey. Diabetes Care 2006; 29: 531-7.

5. American Diabetes Association. 15. Diabetes Care in the Hospital: Standards of Medical Care in Diabetes-2019. Diabetes Care 2019; 42(Suppl1): S173-81.

6. Hood KK, Hilliard M, Piatt G, levers-Landis CE. Effective strategies for encouraging behavior change in people with diabetes. Diabetes Manag (Lond) 2015; 5: 499-510.

7. Ventola CL. Mobile devices and apps for health care professionals: uses and benefits. P T 2014; 39: 356-64.

8. Bravata DM, Smith-Spangler C, Sundaram V, Gienger AL, Lin N, Lewis R, et al. Using pedometers to increase physical activity and improve health: a systematic review. JAMA 2007; 298: 2296-304

9. Rashed OA, Sabbah HA, Younis MZ, Kisa A, Parkash J. Diabetes education program for people with type 2 diabetes: An international perspective. Eval Program Plann 2016; 56: 64-8. 
10. Presset B, Laurenczy B, Malatesta D, Barral J. Accuracy of a smartphone pedometer application according to different speeds and mobile phone locations in a laboratory context. J Exerc Sci Fit 2018; 16: 43-8.

11. Wu LL, Wang KM, Liao PI, Kao YH, Huang YC. Effects of an 8-Week Outdoor Brisk Walking Program on Fatigue in Hi-Tech Industry Employees: A Randomized Control Trial. Workplace Health Saf 2015; 63: 436-45.

12. Kopp M, Steinlechner M, Ruedl G, Ledochowski L, Rumpold G, Taylor AH. Acute effects of brisk walking on affect and psychological well-being in individuals with type 2 diabetes. Diabetes Res Clin Pract 2012; 95: 25-9.

13. Craig CL, Marshall AL, Sjöström M, Bauman AE, Booth ML, Ainsworth BE, et al. International physical activity questionnaire: 12-country reliability and validity. Med Sci Sports Exerc 2003; 35: 1381-95.

14. Talbot F, Nouwen A, Gingras J, Gosselin M, Audet J. The assessment of diabetes-related cognitive and social factors: the Multidimensional Diabetes Questionnaire. J Behav Med 1997; 20: 291-312.

15. Coşansu G, Erdoğan S. Validity and Reliability Study of the Turkish Version of Multidimensional Diabetes Questionnaire (MDQ) in Type 2 Diabetes. Anadolu Hemşirelik ve Sağık Bilimleri Dergisi 2010; 13: 10-8.

16. Ware JE Jr, Sherbourne CD. The MOS 36-item short-form health survey (SF-36). I. Conceptual framework and item selection. Med Care 1992; 30: 473-83.

17. Saleh F, Mumu SJ, Ara F, Hafez MA, Ali L. Non-adherence to self-care practices $\&$ medication and health related quality of life among patients with type 2 diabetes: a cross-sectional study. BMC Public Health 2014; 14: 431.

18. Yom-Tov E, Feraru G, Kozdoba M, Mannor S, Tennenholtz M, Hochberg I. Encouraging Physical Activity in Patients With Diabetes: Intervention Using a Reinforcement Learning System. J Med Internet Res 2017; 19: e338.

19. De Greef KP, Deforche BI, Ruige JB, Bouckaert JJ, Tudor-Locke CE, Kaufman JM, et al. The effects of a pedometer-based behavioral modification program with telephone support on physical activity and sedentary behavior in type 2 diabetes patients. Patient Educ Couns 2011; 84: 275-9.

20. Kokkinos P, Sheriff H, Kheirbek R. Physical inactivity and mortality risk. Cardiol Res Pract 2011; 2011: 924945.

21. Katsuki A, Sumida Y, Gabazza EC, Murashima S, Furuta M, Araki-Sasaki R, et al. Homeostasis model assessment is a reliable indicator of insulin resistance during follow-up of patients with type 2 diabetes. Diabetes Care 2001; 24: $362-5$.
22. Fayehun AF, Olowookere 00, Ogunbode AM, Adetunji AA, Esan A. Walking prescription of 10000 steps per day in patients with type 2 diabetes mellitus: a randomised trial in Nigerian general practice. Br J Gen Pract 2018; 68: e13945.

23. Colberg SR, Sigal RJ, Fernhall B, Regensteiner JG, Blissmer BJ, Rubin RR, et al. American College of Sports Medicine; American Diabetes Association. Exercise and type 2 diabetes: the American College of Sports Medicine and the American Diabetes Association: joint position statement. Diabetes Care 2010; 33: e147-67.

24. Glynn LG, Hayes PS, Casey M, Glynn F, Alvarez-Iglesias A, Newell J, et al. Effectiveness of a smartphone application to promote physical activity in primary care: the SMART MOVE randomised controlled trial. Br J Gen Pract 2014; 64: e384-91.

25. Funk M, Taylor EL. Pedometer-based walking interventions for free-living adults with type 2 diabetes: a systematic review. Curr Diabetes Rev 2013; 9: 462-71.

26. Araiza P, Hewes H, Gashetewa C, Vella CA, Burge MR. Efficacy of a pedometerbased physical activity program on parameters of diabetes control in type 2 diabetes mellitus. Metabolism 2006; 55: 1382-7.

27. Dutton GR, Tan F, Provost BC, Sorenson JL, Allen B, Smith D. Relationship between self-efficacy and physical activity among patients with type 2 diabetes. J Behav Med 2009; 32: 270-7.

28. Indelicato L, Dauriz M, Bacchi E, Donà S, Santi L, Negri C, et al. Sex differences in the association of psychological status with measures of physical activity and sedentary behaviour in adults with type 2 diabetes. Acta Diabetol 2018; 55: $627-35$

29. Cosansu G, Erdogan S. Influence of psychosocial factors on self-care behaviors and glycemic control in Turkish patients with type 2 diabetes mellitus. J Transcult Nurs 2014; 25: 51-9.

30. Guglani R, Shenoy S, Sandhu JS. Effect of progressive pedometer based walking intervention on quality of life and general well being among patients with type 2 diabetes. J Diabetes Metab Disord 2014; 13: 110.

31. Williamson DA, Rejeski J, Lang W, Van Dorsten B, Fabricatore AN, Toledo K; Look AHEAD Research Group. Impact of a weight management program on health-related quality of life in overweight adults with type 2 diabetes. Arch Intern Med 2009; 169: 163-71. 